\title{
Globalization And The Emergence Of New Business Models In The Wine Industry
}

Richard M. Castaldi, (Castaldi@Sfsu.Edu), San Francisco State University Susan Cholette, San Francisco State University April Frederick, San Francisco State University

\begin{abstract}
The forces of globalization have dramatically altered the international competitive landscape of the wine industry. This paper identifies and analyzes four new business models that have emerged among major industry competitors as wineries strive to create sustainable sources of competitive advantage.
\end{abstract}

\section{INTRODUCTION}

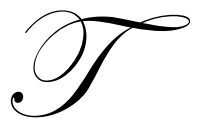

he wine industry is undergoing rapid and radical changes as the forces of globalization are changing the international competitive landscape of the industry. Worldwide consolidation is occurring at the winery, distributor and retail levels creating bigger and more powerful industry players, while an oversupply of grapes is eroding profit margins. As recently as 10 years ago, the industry was localized and fragmented which meant that wine producers in different countries were relatively insulated from each other, and most wine drinkers consumed domestic products. Today, consumers around the globe have the opportunity to purchase wine produced from virtually every region of the world and this has forged exciting new opportunities, along with formidable challenges to wineries worldwide.

A major opportunity for wineries is the expansion of potential sales beyond their domestic markets due to decreasing international trade barriers and changing consumer behavior patterns. Major challenges include increased competition from strong foreign wineries, and retail pricing pressures due to industry overcapacity. For instance, exports now command greater than $25 \%$ of the US market revenue, almost double that of ten years ago. This new industry paradigm is changing how firms choose to compete. In August 2004, recently elected Chairman of Robert Mondavi Corporation, Ted Hall observed, "It has become increasingly clear that in the new wine environment, wines require different business models" (Bonne, 2004). Based upon numerous interviews with industry executives, as well as a comprehensive review of trade and academic literature, this paper will identify and analyze four business models that have recently emerged as firms strive to create competitive advantages to confront the forces of globalization that are sweeping the industry.

\section{EMERGING BUSINESS MODELS IN THE WINE INDUSTRY}

One way firms adjust to a turbulent business environment is to change their business model to better fit the new competitive and consumer demands of the industry. A business model is defined as a value chain framework in which a company operates to create sustainable competitive advantages. It identifies a strategic set of activities that firms perform to benefit customers and to achieve profitability.

Research shows that major wine industry players have adopted four different business models in recent years. These models are classified as "Largest Player", "Lone Ranger", "Wine Groups", and "Diversified Conglomerate". Each business model has attributes that can help create competitive advantages. For example, both the Largest Player and Wine Groups business models use economies of scale in innovation, production and 
marketing as sources of competitive advantage. The Diversified Conglomerate business model relies on economies of scope where the company combines activities to create efficiencies through the value chain to build competitive advantages. The Lone Ranger business model primarily focuses on brand and product development, as well as identifying underserved markets to create competitive advantage.

The largest winery in the world is E. \& J. Gallo and their size alone (it controls over $25 \%$ of the US market by volume) creates a unique business model called Largest Player. Their size makes it hard for other companies to match their economies of scale benefits, as well as their distribution and marketing power. Recently, Gallo was surpassed as the largest wine company in the world by the merger of BRL Hardy and Constellation Brands. This merger is likely the harbinger of future alliances between major players as they see the benefits that large size creates in coping with the current wine environment. Gallo is also diversifying their product line by increasing their wine portfolio by through acquisition of producers known for their higher retail value such as their recent purchase of Louis Martini Winery.

Lone Ranger wine companies comprise the majority of wine companies currently in the industry. Lone Ranger wineries can be 1) a single location winery, 2) one that has no brick and mortar structure but produces wine on a contract basis, or 3) wineries that own multiple properties but operate under a single set of labels. Robert Mondavi Corporation and the Delicato Family Vineyards will be profiled and analyzed as examples of this business model. Lone Ranger wineries use a common business model, but can be very different in how they manage operations, distribution channels, and their customer base.

Wine Groups are defined as companies that have a portfolio of different wineries and labels offering different brands but are all held by one company. Chalone Wine Group is analyzed as an example of this business model. They own and operate wineries that offer wines in the luxury wine price segments. Their model revolves around owning many wineries that fit into different high-end segments of their customer base. Chalone Wine Group diversifies their product offering based on varietals and regions while other wine groups may choose to diversify their companies based on retail price segments.

The fourth business model that has been identified is the Diversified Conglomerate. Brown-Forman, Inc. and Diageo, LLP are profiled and analyzed as examples of firms using this business model. Both of these companies have wineries in their portfolio, along with other businesses. Conglomerates were lured back into the wine industry during the 1980s and 1990s due to the high growth rate in wine. In 2003, wine shipments grew by $4 \%$ while wine retail sales increased in value by $2.3 \%$ (Wine Institute 2004). The next section will profile these six firms and analyze the four business models in greater detail.

E.\& J. Gallo was founded in 1933 in Modesto, California by two brothers, Ernest and Julio Gallo. The Gallo brothers started their enterprise with the grape growing facility passed down from their parents, $\$ 5,900$ and two pamphlets on wine making from the public library (Lukacs 2000). Julio Gallo oversaw the winemaking while Earnest handled the marketing and distribution and studied wine consumers carefully.

One of Gallo's first successes was with Thunderbird brand of fortified wines in the 1950s. Thunderbird was marketed in the inner city and in low income areas and it topped the sales charts in these locations. By the 1960's and 70's Gallo shifted its focus to other table wine varieties with higher quality and price points and began forming long term growing contracts. These long-term contracts allowed the growers the safety to experiment with planting different varietals because of the stability of cash flows that the contracts generated.

Gallo is a privately owned and family operated business with the second and third generation family members currently working within the company and employs more then 4,600 people in over ninety countries. Their official vision is "To become the most innovative global marketer and distributor of wines". Their corporate priorities are: to attract, retain and develop a high-performing, diverse organization, continuously improve their product quality and product offering as defined by the consumers, and lastly to expand and strengthen their distribution network. Gallo's strategy for achieving its vision is to relentlessly focus on the customer; strive for 
continuous improvement in themselves, their processes and their products. They constantly challenge industry assumptions and encourage breakthrough innovations and often collaborate cross-functionally (www.Gallo.com).

\section{Exhibit 1: Business Model Typology of the Wine Industry}

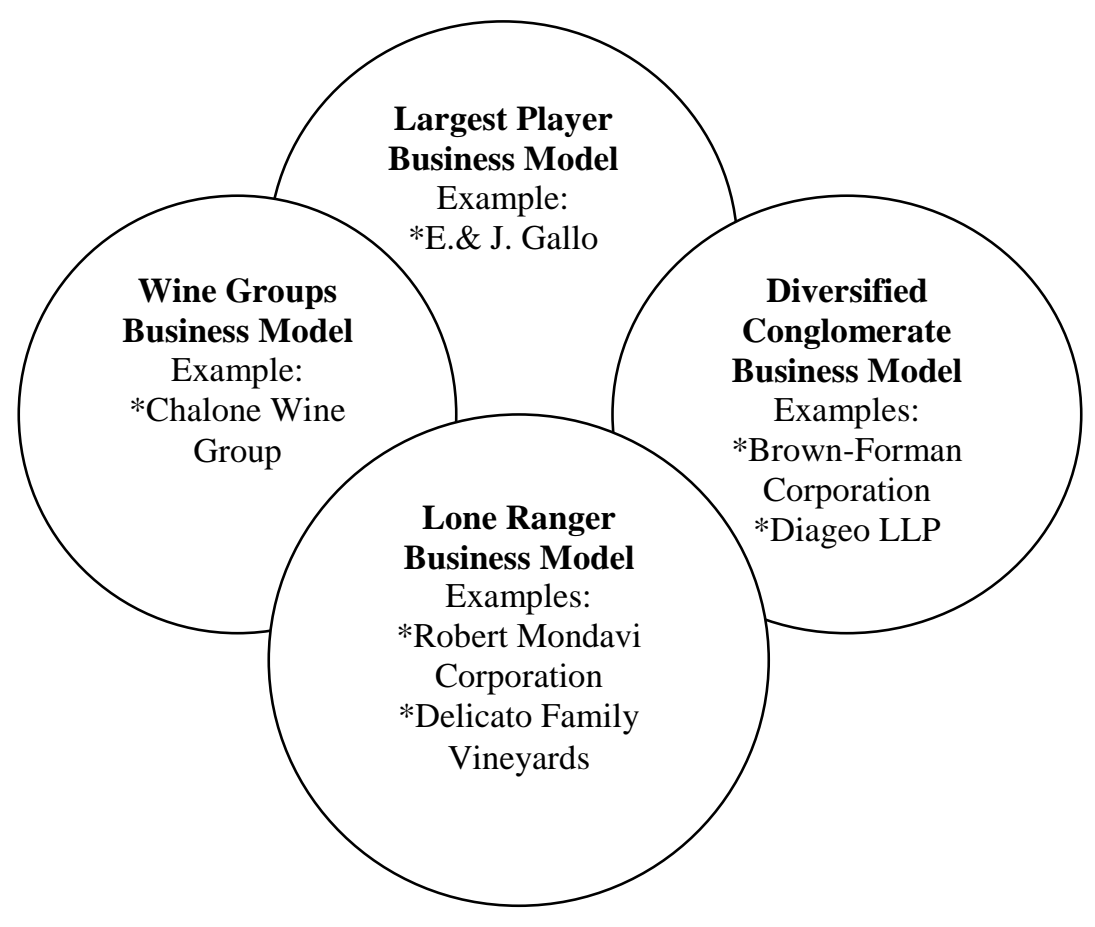

\section{LARGEST PLAYER BUSINESS MODEL}

In order to control costs and to position future products in the retail markets, Gallo integrated forward into the distribution channel. This forward integration was considered one of their greatest competitive strengths and complemented their ability to get visible floor space in retail establishments. Gallo has also integrated backward into bottling plants and foil producers, as well as owning a significant portion of their vineyards. They also pioneered the development of new wine production techniques and growing high quality grapes. The innovations made in those two areas helped them produce consistently high quality wine for lower costs. This enabled them to capture a very large portion of the low-end table wine market. After establishing a dominant position in the lower price/high volume wine segment, Gallo made the move into the higher price/low volume premium markets. These examples of economies of scale, forward and backward integration, positioning, and innovations have all contributed to their significant competitive advantages.

The Gallo business model is fundamentally that of a Lone Ranger wine company. However, their sheer size makes them singularly unique, and thus different then other stand alone players as to their sources of competitive advantages. Globally, Gallo has been the number one player but that position was recently usurped by the merger between the US's Constellation and Australia's BRL Hardy which combines the resources of many wineries. Those companies also sell beer and spirits and generate \$3.2 billion in annual sales, and the wine division accounts for \$1.7 billion. In 2002, the annual estimated wine sales for Gallo was $\$ 1.4$ billion (Emert 2003). In the United States market, Gallo continues to be the dominant industry player with a $26 \%$ market share (by volume) of all wine in the US, as well as being the leading exporter of wine. 
This ubiquitous size advantage over other wineries has given Gallo unprecedented economies of scale benefits in innovation, production, distribution and marketing segments of the value chain, and has been the source of significant competitive advantages over their smaller rivals. The efficacy of the Largest Player business model is reinforced through the recent merger of BRL Hardy with Constellation Brands. It is expected that other major players in the wine industry will follow suit by merging and pursuing this type of business model because of the tremendous market power and economy of scale benefits it creates.

\section{LONE RANGER BUSINESS MODEL}

\section{Robert Mondavi Winery}

Robert Mondavi founded the Robert Mondavi Winery (RMC) in 1966 at the age of 54 after his departure from the family-owned Charles Krug Winery. Robert Mondavi used personal savings and loans from friends to start up his Napa Valley winery with a simple vision: "To do whatever it took to make great wines and to put Napa Valley on the map, right alongside the great winemaking centers of Europe."

Robert Mondavi's initial business plan called for building RMC's reputation by producing a limited quantity of super to ultra-premium wines using the most prestigious varietal grapes: Cabernet Sauvignon, Pinot Noir, Chardonnay, and Johannesburg Riesling. At this point in time these grape varietals commanded the highest prices in the marketplace and had the highest profit margin per bottle. In order to generate cash flow to expand the business, RMC planned to produce less expensive wines in high volumes to be sold in the premium market. Robert Mondavi then built a state-of-the-art winemaking facility that was both functional for making premium wines and sufficiently unique to make a statement about the wines the facility produced. Mondavi enlisted a highly respected architect, Cliff May, to design an eye-catching Spanish mission-style landmark that became the backdrop of every wine label RMC produced.

The RMC winery became a laboratory for developing what became some of California's best practices in the production of world-class premium wines. Among these best practices were 1) assembling a team of experts in the areas of viticulture and winemaking from industry professionals to university professors, 2) developing new technology to permit gentle handling of wine grapes and cold fermentation of white wines, and 3) process innovations such as steel fermentation tanks, vacuum corking of bottles, and aging of wines in new French oak barrels. By the early 1990s, RMC developed severe financial constraints brought on by the combination of expansion, increased competition, and an infestation of phylloxera. Further compounding problems for the company was the emergence of 200 new wineries in the Napa Valley, many of which were now producing premium to ultrapremium wines that directly competed with RMC brands.

Robert Mondavi decided to take his company public to obtain needed growth capital. On June 10, 1993, RMC issued 3.7 million shares at $\$ 13.50$ a share and began trading on the NASDAQ exchange under the symbol MOND. The IPO raised approximately $\$ 49.95$ million, giving the company a market capitalization of $\$ 213.3$ million. However, within days the stock was trading at around $\$ 8$ a share and six months later at $\$ 6.50$ a share, wiping away over half of the company's value and half of the Mondavi family's fortune. Investors and analysts alike had difficulty in valuing RMC due to a lack of information on the company and the wine industry as a whole.

By the mid-1990s, the company had entered into three multi-national partnerships, one in Napa with the Rothschild family, one in Chile with the Chadwick family and the other in Italy with the Marchesi de' Frescobaldi family. These partnerships yielded several new global brands, including Opus One, Caliterra, and Lucente. Mondavi believed the formation of global joint ventures would become an integral part of RMC's future business and a way for the company to continue to innovate and develop world-class wines. He wanted RMC to become a truly global company by growing, producing, and selling wines in all the best wine-growing regions in the world.

In 2004 RMC announced that Ted Hall would become Chairman of the Board. This was to be the first time that a non-family member was appointed to an executive position. In February 2004 Wine Business Monthly named RMC as number 6 out of the top thirty US wine companies. Michael Mondavi had this to say about the future: 
"There are more people drinking wine and for the first time in my experience, the young adult is interested in wine. There's a great opportunity to communicate with the 25 to 35 year olds, tomorrow's customer." He then discussed the industry's future, "We should be able to produce wines of higher quality as efficiently as any producer in the world. In the 1960s, people didn't recognize California as making great wines" (Wine Business Monthly 2004).

This emphasis by RMC on innovations in brand product development and identifying under served consumer groups are typical sources of competitive advantage by firms adopting a Lone Ranger business model. Their product innovations and ability to attract new types of wine drinkers in recent years has positioned RMC very favorably to compete successfully in this industry that is being changed dramatically by the forces of globalization.

\section{Delicato Family Vineyards}

Delicato Family Vineyards (DFV) is one of California's leading family winegrowers with a history going back over 75 years. The Indelicato family originally began growing wine grapes and making wines in a small village in Italy. In 1924 the Indelicato family immigrated to California from Sicily and purchased a 40-acre dairy farm in Manteca, California. The family converted the dairy farm into a grape vineyard and called it Delicato Family Vineyards. DFV is a privately owned company with financial information unavailable to the public. Gaspare Indelicato began making wine after Prohibition. Delicato was able to expand as a number of companies in the California wine industry approached DFV to make wines for their own label. Increasing demand for its private label wines lead DFV to purchase additional vineyards to maintain a consistent supply of grapes.

In the 1970's, DFV developed a number of long-term agreements with a variety of other wineries to create custom label wine for other wine companies. As business increased, DFV was able to generate strong revenue streams, allowing them to significantly expand their bulk wine production infrastructure. In 1988, the DFV family bought San Bernabe Vineyards. After the purchase of San Bernabe Vineyards DFV began a ten-year process of replanting on the property using sustainable wine growing methods. San Bernabe uses many natural practices on its 8700 -acre vineyard and the family philosophy embodies finding environmental balance with grape farming techniques (Wine Institute 2002).

Eric Morham joined DFV in March of 1999 to head up a major transformation of the company in order to increase the recognition, status and prestige of DFV. He compressed the company's reporting hierarchy to flatten its organizational structure and brought in a new management team with nine people reporting directly to him. This new management team at DFV had a new vision for the company which was to be the best in class in the art and science of selling wine. Eric Morham also evaluated the different business segments of DFV to understand the value and importance of each segment to the new strategic orientation of the company. DFV is involved in three business segments; agriculture, bulk wine, and branded wine business for DFV brands. Both DFV agriculture and bulk wine/business-to-business (B2B) segments were the original businesses of DFV and they contributed about two-third of the company's total sales revenues.

Although DFV's branded case business, started in the 1990s, only contributed one-third of the company's total sales revenue, this segment was very profitable with consistently high profit margins. DFV made the strategic decision to grow its branded business segment and the goal was to have it be two-thirds of its total sales revenues. The remaining one-third of firm revenues would be generated from its traditional agricultural and B2B businesses that are needed to support the growth-oriented branded business. DFV was dedicated to building its wine brands by focusing on the "value equation," creating good wine at several different price points, each brand attractively packaged and supported by a strong sales and marketing organization (Castaldi, 2003).

DFV is also focusing on attracting younger consumers with a new product called Bota Box. This packaging innovation was created for the younger generation of wine drinkers as recent studies show that core drinkers, people who consume wine more then once a week, is growing by more then thirty percent (Wine Business Monthly 2002). These strategic moves are examples of building competitive advantages through brand and product development and through packaging innovations and are a hallmark of the Lone Ranger business model. 


\section{WINE GROUPS BUSINESS MODEL}

Chalone Wine Group (CWG) states as its mission to "Be a unique family of pioneering wineries, proudly working together to grow and market world-class wines that reflect the historic soils from which they came and the passionate commitment of the people involved." A Frenchman named Charles Tamm started Chalone Winery in 1919.

After going through many different owners, Chalone Winery was purchased by Richard Graff in 1966. In 1974 Phil Woodward joined Chalone Winery and became President. Along with a few other partners he formed Chalone Wine Group. In 1984 CWG was the first fine wine company to be publicly traded on the NASDAQ. CWG had built their reputation in ultra-premium wines. Tom Selfridge was named President and CEO in 1998. In 2002 CWG had 169 employees, a sales growth rate over $54 \%$.

Chalone Wine group owns wineries in California, Oregon, and France. To take advantage of this business model, CWG strategy is to use economies of scale in buying packaging material for all the brands it operates as a source of competitive advantage. According toTom Selfridge, "We're kind like the patron of the arts. We provide the nuts and bolts and the more boring things for winemakers. That leaves them free to make the wine." (Heeger 2003).

CWG has entered into two partnerships and one is an equal relationship with Paragon Vineyard in the Edna Valley with Paragon owning the vineyard and CWG owning the winery. The other is CWG's $23.5 \%$ interest in Chateau Duhart-Milton in Bordeaux, located next to Chateau Latife-Rothschild. Le Domaines Barons de Rothschild, controlled by Chateau Lafite, owns a $46 \%$ share in CWG as well as the remaining interest in Chateau DuhartMilton. Christopher Salin, president of Le Domaines Barons de Rothschild, is also chairman of the board of CWG. Eric de Rothschilde, Magaging Partner of Lafite, is also on the board of directors at CWG (Heeger 2003).

Chalone exports about $5 \%$ of its wine produced in the US. Tom Selfridge told the Napa Valley Register, "I want us to be in better accounts overseas, but we'll never see a lot of export volume because of our price points."(Heeger 2003). CWG follows the traditional French practice of "terroir" and their web site states:

"Chalone Wine Group's approach to wine is based on the concept of terroir, a French term for the countless geographic, topographic and climatic elements that define a growing region or vineyard site and make it unique. Each of the semi-autonomous wine estates and vineyards within CWG has an identity shaped by the region and particular site in which it is located, and produces wines that reflect that unique place. By centralizing administrative functions such as finance, sales and marketing, CWG serves as a patron of the wine arts, enabling each winery to focus full attention on crafting the finest possible wine."(http://www.chalonewinegroup.com)

In a presentation that Tom Selfridge gave at the 2003 Wine Symposium in California he stated that CWG is looking ahead at both the increased competition both domestically and globally, as well as at advances in technology. CWG recently put in a web-based application to streamline its bottling and labeling operations. Tome Selfridge believes that CWG cannot compete long term in the jug wine or in the super value, as he believes providing top quality at higher price points will always prove to be the best strategy for CWG. Selfridge believes in differentiating CWG products by packaging, flavor and a sense of place, along with fair pricing.

CWG maintains a diverse portfolio of regional and varietals offerings within a specific price range and is always searching for opportunities in undervalued grape growing regions. Their practice of owning and controlling most vineyards, along with consolidating purchasing needs achieves economies of scale, yet still allows each winery to have its own personal style and image. CWG uses these tactics to provide the edge that it needs to succeed in the global market place. Creating such economies of scale in production and marketing functions to use as sources of competitive advantage is a primary benefit of utilizing the Wine Groups business model. 


\section{DIVERSIFIED CONGLOMERATE BUSINESS MODEL}

\section{Brown-Forman Corporation}

Brown-Forman Corporation (BFC) was one of the pioneering firms to adopt the Diversified Conglomerate business model with holding in the distilled spirits, wine and luxury consumer goods industries. Brown-Forman is based in the United States and a public company traded under the ticker BFD.

In 1870 George Brown and John Forman started Brown-Forman in Louisville, Kentucky to produce Old Forster brand bourbon. John Forman died in 1901 and George Brown bought out John Forman's interest in the company. Brown-Forman was one of the few companies allowed to produce alcohol during prohibition in the 1920s for medicinal purposes. Brown-Forman went public in 1933.

In the 1980s, BFC diversified into luxury consumer goods with the purchase of well-known global brands and purchased Lenox, Hartmann luggage, Dansk, and Gorham tableware and giftware. By 2002 BFC subsidiary locations and manufacturing branches included production facilities in the US, two in Italy and one each in Canada and the Virgin Islands. The consumer goods segment also owned facilities in New Jersey, North Carolina, Pennsylvania, Rhode Island, and Tennessee.

Brown-Forman is a publicly traded company but is closely held by the Brown Family. The Fifth generation family members are currently working within different levels in the corporation. The Wine and Spirits division included the operations, manufacturing, bottling, importing, exporting, and marketing of all alcoholic beverages (spirits, champagne, and wine). BFC distributes products in this segment domestically through state agencies or wholesale distributors and uses contracts with authorized dealers for international distribution. BFC has also maintained a significant presence in export markets via its own international division that is responsible for marketing Fetzer and other BFC wine brands.

Fetzer Vineyard has recently expanded its organic growing campaign and hired scientist L. Ann Thrupp to manage organic development at the winery. Thrupp told Wine Business Monthly that Fetzer is focusing on organic growing, not just on organic wine making. While organic wines have a shorter shelf life because they lack sulfur, Thrupp believes that there are many business benefits to organic growing. By eliminating the need to purchase pesticides and other chemicals used in grape growing, organic wines have a cost advantage. Another benefit is the appeal to consumers sensitive to environmental issues, a growing market segment, especially in Europe. Market research shows that UK consumers are willing to pay a higher price for organic wines. Moreover, sales of Bottera organically grown wine doubled between 1988 and 2002, from 58,000 cases to 100,000 cases.

One source of competitive advantage of the Diversified Conglomerate business model is the ability of BFC to utilize its resources and proprietary knowledge across its spirits, champagne and wine segments to create competitive advantages in product innovation, as well as operational efficiencies in other value chain activities. The economies of scope benefits realized by BFC have been instrumental in making them into one of the world's most successful players in the industry. It is also the primary reason the use of the Diversified Conglomerate business model will likely continue to increase in the industry.

\section{Diageo LLP}

Diageo LLP based in London, England, was created in 1997 through the merger of two British companies, Grand Metropolitan plc and Guinness plc. Diageo, from the Latin word for "day" and the Greek word for "world", currently competes in the food, alcoholic beverages and fast food restaurants, though it recently announced its intention to exit from all sectors except the alcoholic beverage industry.

Paul Walsh, Diageo's CEO recently stated his strategy is to focus on the 'drinks' business. In 2000, Walsh merged Guinness Brewing with United Distillers and Vintners to create a more focused core of beverages businesses (now named Guinness UDV) upon which to build future earnings growth. In December 2000, Diageo and the 
French company Pernod Ricard agreed to jointly purchase Seagram's alcohol assets and divide them between the two companies. Diageo paid \$5 billion, while Pernod Richard contributed $\$ 3.15$ billion to the deal. Following the acquisition of Seagram's liquor and wine portfolio, Diageo became the largest spirits and wine holding company in the world. The acquisition included two major California brands, Sterling Vineyards and Beaulieu Vineyards, as well as importing rights and/or partial ownership in nearly 200 French wines and champagne, including many estatebottled French Burgundies, wines from Barton \& Guestier (Bordeaux, France), and F.E. Trimbach wines (Alsace, France).

Diageo created a separate division for its wine group called. Diageo Chateau \& Estate Wines produces and markets wines from Beaulieu Vineyard (BV), Sterling Vineyards, Sterling Vintner's Collection, Blossom Hill and the Monterey Vineyard. In the US, the company is the largest importer of French wines. Global wine production for Diageo totaled about 8 million cases in 2003 (Wine Business Monthly 2004). In an interview January, 2002 interview with Wine Business Monthly, Ray Chadwick, Board Chair, commented on Diageo's future relationships with its distributors:

"Let me address this very directly. [We want] to develop a more efficient and effective way of bringing [our] total portfolio of products - including wines - to market. We want to create a new way of working with our distributors and brokers. Over the coming months we will begin a process with our distributors and brokers to develop this new kind of relationship. And we can foresee the possibility of adjustments to our distributor network in the next year or eighteen months, but that process is just beginning. In broad strokes, the new relationship will be more collaborative, more fact-based, more long-term, and more focused on delivering greater value to consumers and customers: understanding the consumer better, understanding customers and consumers better, for example, working with our distributors to really fine tune our channel strategy."

Thanks to the successful implementation and utilization of the Diversified Conglomerate business model, Diageo's significant size and market presence in wine, beers and spirits provides them with the power to increase distributor responsiveness. Diageo can also leverage their combined buying power across all beverage divisions to gain other competitive advantages throughout the value chain. Because of their ability to reconfigure their relationship with industry distributors and brokers, as well as their economy of scope benefits Diageo is positioned well to succeed and take advantage of the opportunities created by the forces of globalization.

\section{CONCLUSIONS}

This paper has presented four new business models that have recently emerged as strategic responses to the forces of globalization that are sweeping the wine industry. The identification of these business models emanated from numerous interviews with industry executives, as well as a comprehensive review of trade and academic literature. The wine industry is changing rapidly and radically and the industry rivals are intensifying the fight for market share in both domestic and foreign markets. To meet the challenges in this globalizing industry new sources of competitive advantage are being created by the strategic shift of organizational resources throughout the value chain activities in the form of these business models.

Of course, many firms in the wine industry throughout the world will continue to compete by remaining small and serving a targeted niche market. However, the forces of globalization will continue to bring more and more consolidation at the producer, distributor and retail levels so firms wishing to compete in global markets will need to assess their current organizational structure, strategies and sources of competitive advantage as stronger and bigger players emerge. The four business models identified as the Largest Player, Lone Ranger, Wine Groups and Diversified Conglomerate appear to work well in terms of creating competitive advantages for the six firms that were profiled and analyzed in this paper. Given their successful applications, these business models should be considered for strategic and competitive reasons by other global players in the industry.

It is important to note that due to the forces of globalization these business models are organic structures and movements between them can be expected. A perfect example is the November, 2004 acquisition of Robert Mondavi (a Lone Ranger) by Constellation Brands that effectively moves the combined operations into the "Largest 
Player" model with Gallo. Post-merger, Constellation Brands will have combined 2003 U.S. sales of 76 million cases that makes it slightly larger than Gallo who sold 75 million cases of wine. This current example of industry consolidation supports the veracity of our four business models as firms strive for sustainable sources of competitive advantage in the wine industry.

Finally, a strategic map of the firms profiled is presented below. The purpose of this particular map is to visually depict where the six wine companies that are using the four business models are competing based on their distribution and price segmentation strategies. As indicated, Diageo, BFC, Gallo and Mondavi compete globally across all price points, while CWG and Delicato choose to compete domestically at very different price points. Other strategic variables could also be analyzed as such to generate further competitive insights.

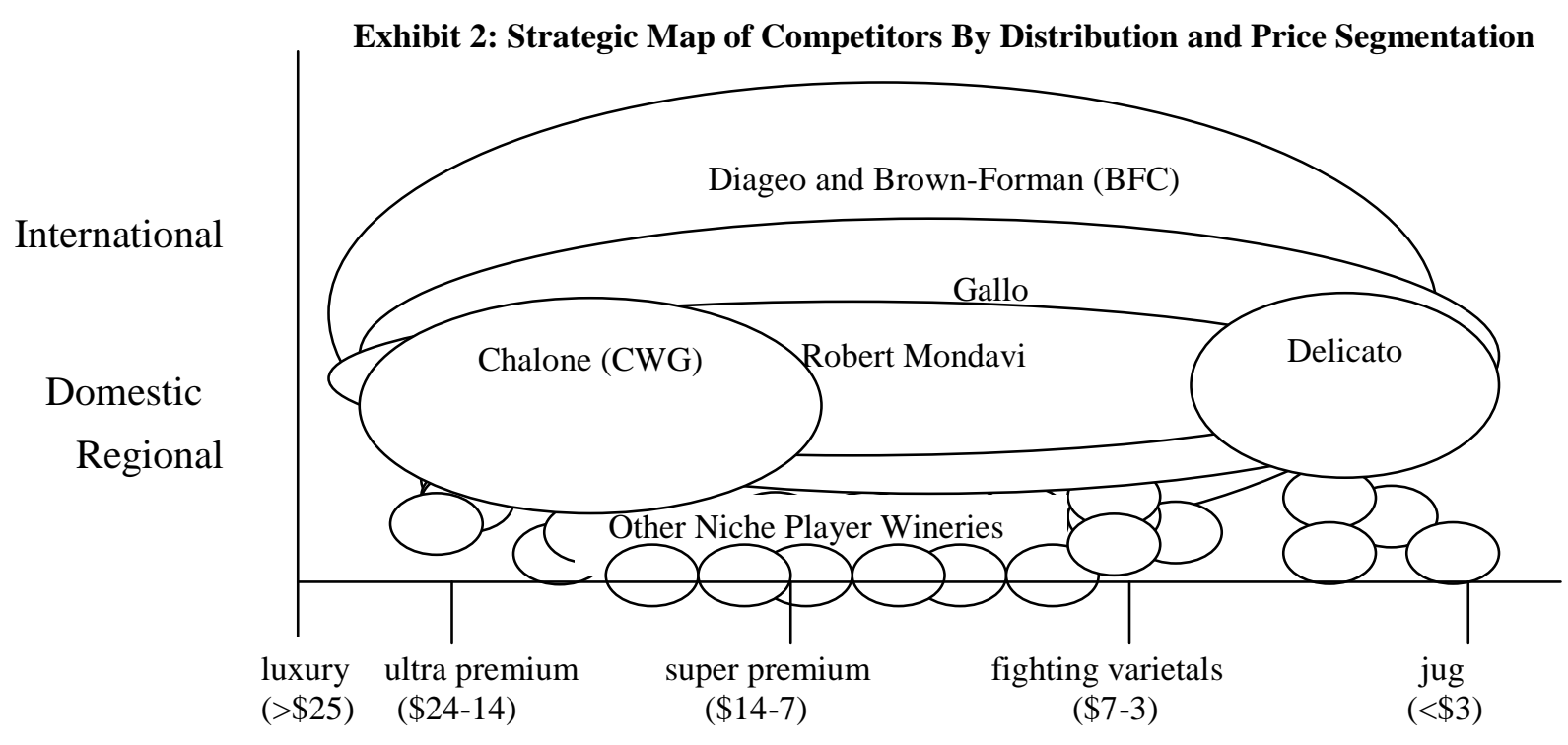

In sum, four business models that have recently emerged in the wine industry to counter the prevailing forces of globalization were presented as examples of successful sources of sustainable competitive advantage. Other firms that wish to compete in the global wine market may want to review their current value chain configuration to determine if there are structures and strategies available to better adapt to the competitive and consumer changes that are currently sweeping the wine industry.

\section{REFERENCES}

1. $\quad$ Adams Beverage Group. 2003. Adams Wine Handbook. Connecticut: Bev-Al Communications Inc.

2. Arno, Andrew. 2002. Globalization of the Wine Industry. Wine Business Monthly April Available from http://winebusiness.com/html/MonthlyArticle.cfm?aid=54002\&issueid=53965

3. Bonné, Jon. 2004. Split in Mondavi empire is a telling one. MSNBC. 26 August, Available from http://msnbc.msn.com/id/5821902/

4. Brown-Forman. 2004. Annual Report. Available from http://www.brown-forman.com/

5. Castaldi, Richard, Sengupta, Sanjit, Silverman, Murray. 2001. "The Performance of U.S. Wineries in the Global Marketplace". Western Academy of Management Conference, April. Internet. Available from http://online.sfsu.edu/ castaldi/bie/west2001.html; accessed 3 October 2003.

6. Chalone Wine Group. 2003. Annual Report. Available from http://www.chalonewinegroup.com/ financials/financials.htm

7. E. \& J. Gallo. Internet. Available from http://www.gallo.com 
8. $\quad$ Emert, Carol. 2003. "New Global Wine Giants even Bigger then Gallo More Competition for the California Wineries". San Francisco Chronicle 18 January, section D5.

9. Franson, Paul. 2003. Fetzer Vineyards ups the ante in organic growing. Wine Business Monthly June Available from http://winebusiness.com/html/MonthlyArticle.cfm?aid=73766\&issueid=73745

10. Heeger. Jack. 2003. Expanding in Napa Valley. Napa Valley Register 28 August, 1.

11. Lukacs, Paul. 2000. American Vintage: The Rise of the American Wine. New York: Houghton Mifflin Company.

12. Robert Mondavi Corporation. Internet. Available from http://www.robertmondaviwinery.com/

13. Rosen, Maggie. 2004. Gallo to launch French wine in America. Decanter.com, 10 March, Available from: http://www.decanter.com/news/48099.html

14. Smiley, Robert. 2003. 2003 "Wine industry financial survey". Presented at 2003 Wine industry symposium, September 25-26, Napa Valley Marriott, Napa, California

15. Wine Business Monthly Staff. 2002. The Top Ten Business Stories of 2002. Wine Business Monthly. December, Available from http://winebusiness.com/html/MonthlyArticle.cfm?aid=64076\&issueid=64069

16. 2004. "The Top 30 US Wine Companies". Wine Business Monthly. February 78-86.

17. Wine Institute. 2002. "Despite economic conditions, September 11 and the strong dollar, 2001 California wine shipments up one percent". April. Internet. Available from http://www.wineinstitute.org /communications/statistics/Sales_01.htm; accessed 29 September 2003.

18. _ 2004. "2003 California Wine Shipments to the US Rise Four Percent: Market Poised for Growth Amid Intense Competition". Available from http://www.wineinstitute.org/communications/ statistics/ Sales_03.htm 1 April. 